DOI: $10.17805 /$ zpu.2018.2.15

\title{
Брянский текст: пути и способы формирования
}

\author{
О. В. ВОРОНИЧЕВА
}

\author{
БРЯНСКИЙ ГОСУДАРСТВЕННЫЙ ИНЖЕНЕРНО-ТЕХНОЛОГИЧЕСКИЙ УНИВЕРСИТЕТ
}

Статья выполнена в рамках семиотического подхода к изучению города, который рассматривается как текст, т. е. в единстве элементов, составляющих его смысловое поле и выполняющих знаковую функцию. Предметом анализа являются процесс и результат символизации пространства, протекающий в конкретном среднерусском городе с более чем 1000-летней историей.

Выявлены и описаны четыре основных периода развития брянского текста: 1) подготовительный (начало 1880-х годов - 1917 г.), 2) послереволюционный (1918 г. - начало 1930-х годов), 3) советский (начало 1930-х годов - 1985 г.), 4) современный (с 1985 г.). Все эти разные, порой взаимоисключающие друг друга по доминирующей идее и содержанию уровни выстраиваются в единое целое благодаря системе устойчивых образов, соотношение и место которых в культурном пространстве Брянска заметно менялось в зависимости от идеологической составляющей эпохи. Определяющее влияние на содержание и интенсивность развития брянского текста оказывают способы его формирования. Гораздо большее идейно-тематическое разнообразие демонстрируют соотносимые со сменой идеологий революционный и современный периоды, чем советский, характеризующийся тотальным контролем власти над всеми процессами в культурной сфере.

Исследование выявило истоки идейно-тематического разнообразия, внутреннюю логику и противоречия брянского текста, этимологию его смысловых констант. Была определена его вершинная точка, совпадающая с творчеством Л. И. Добычина, после которого на семь десятилетий теряется интерес к самобытности локуса и меняются способы формирования брянского текста. Описана Покровская гора как отдельная семиотическая система, полноценно реализующая главную идею брянского текста и играющая особую роль в раскрытии образа Брянска как города-воина, исконно стоящего на рубеже русской земли. Отмечена значимость астионима Брянск в обеспечении смыслового единства брянского текста и сохранении сути древнего города с особой исторической судьбой и ландшафтом.

Ключевые слова: семиотическая система; Брянск; брянский текст; культурный ландшафт; смысловые константы

\section{BВЕАЕНИЕ}

$\mathrm{B}$ гуманитарном знании сегодня активно используется понятие локального текста. Впервые оно появилось в работах В. В. Абашева о пермском тексте (Абашев, 2000: 36). Сама идея локального текста восходит к работам Н. П. Анциферова о Петербурге (Анциферов, 1990), а наиболее полное раскрытие получает в трудах ученых тартуско-московской семиотической школы, яркими представителями которой являются В. Н. Топоров, Ю. М. Аотман, Б. А. Успенский, 3. Г. Минц и др. У В. Н. Топорова представлен и Петербург как текст, и петербургский текст в русской литературе. Опираясь на специфику петербургского текста, ученый определил особенности городского текста, важнейшей из которых является единство и семантическая связность (Топоров, 1995). Критерии для рассмотрения города как семиотической системы выделил Ю. М. Аотман. Он предложил рассматривать город с различных позиций: город как имя, город как пространство, город как время (Иотман, 1993: 84-92).

А. П. Аюсый пишет: «...своей концепцией “Петербургского текста" В. Н. Топоров бросил методологический вызов России, и та ответила ему текстуальной революцией гуманитарного знания. Вызов заключался в заявленной эксклюзивности данной концепции, постулирующей ее “непереносимость” на другие пространства. Ответ - в по- 
всеместном учреждении разнообразных локальных “текстов культуры” разного уровня и масштаба: московского, киевского, сибирского, алтайского, уральского, волжского, саратовского, самарского, кавказского, вятского, елецкого, муромского, северного и т. А.» (Июсый, 2015: Электронный ресурс).

Активно исследуется калининградский текст (Гаврилина, 2011), особую известность приобрели крымский текст русской литературы (Аюсый, 2012: Электронный ресурс) и пермский текст культуры (Абашев, 2000). Работы, например, В. В. Абашева о пермском тексте выполнены в той же исследовательской парадигме, что и работы В. Н. Топорова: ученый разделяет Пермь как текст (русской культуры) и пермский текст в русской литературе. Однако он исходит из положения о том, что свой локальный текст имеет «любой исторически и культурно освоенный и продуцирующий культурную информацию локус» (Абашев, 2000: 21). Особый интерес к городу обусловливается концентрацией в нем культуры. Город рассматривается как сложная знаковая система, «котел текстов и кодов, разноустроенных и гетерогенных, принадлежащих разным языкам и разным уровням» (Топоров, 1995: 453).

Широкое понимание текста, установившееся в современной семиотике, «дает возможность рассматривать в качестве такового архитектуру, живопись, фотографию, рекламу, повседневные практики» (Гаврилина, 2011: 76), литературные произведения, легенды, городской фольклор, природный ландшафт. В своей совокупности все эти тексты репрезентируют образ города, а их концептуализация создает смысловое поле, необходимое для полноценной жизни человека.

Аанная статья построена на понимании локального текста как семиотической «системы, порожденной конкретным пространством» (Голубев, 2014: 9), отражающей его специфику и «являющейся знаковой его манифестацией» (Гаврилина, 2011: 75). Аокальный текст представляет собой «более или менее стабильную сетку семантических констант, формирующуюся в стихийном и непрерывном процессе символической репрезентации места» (Абашев, 2000: 11).

Разновидностью локального текста является брянский текст - интереснейшее, но совершенно не изученное явление. Мы задались целью доказать положение о том, что Брянск представляет собой сложную семиотическую систему, характеризующуюся единством содержания и многообразием способов его репрезентации. Аля этого выявили специфику формирования брянского текста, проанализировали систему доминирующих образов и сюжетов, способствующих раскрытию главной идеи - древности города, определившей его предназначение, облик и судьбу.

\section{ИСТОКИ БРЯНСКОГО ТЕКСТА (НАЧААО 1880-Х ГОАОВ - 1917 Г.)}

Несмотря на почтенный возраст Брянска, брянский текст сложился относительно недавно. Мы выделяем четыре гетерогенных периода его развития: 1) подготовительный (начало 1880-х годов - 1917 г.), связанный с представлениями о Брянске В. И. Немировича-Аанченко, В. В. Розанова и К. Г. Паустовского; 2) послереволюционный период брянского текста (1918 г. - начало 1930-х годов), ознаменованный прежде всего творчеством $\Lambda$. И. Аобычина и социалистическим преобразованием культурного ландшафта Брянска; 3) советский (начало 1930-х годов - 1985 г.), характеризующийся приоритетным вниманием к темам Великой Отечественной войны, трудового и революционного прошлого города; 4) современный (с 1985 г.), наследующий идейнотематическое разнообразие предыдущих эпох и отличающийся сформированной системой смысловых констант. Единство брянского текста обеспечивает имя города, 
которое имеет столь же древнюю историю, как и сам Брянск: за десять с лишним столетий своего существования он никогда не переименовывался. Менялась только огласовка астионима: в 1147 г. упоминается Аъбряньск, Бряньск и Аебряньск, т. е. при существовавшей вариантности названия уже в середине XII в. встречалась форма Бряньск.

Предпосылки осмысления брянских реалий мы можем наблюдать уже в народном творчестве, в частности в зафиксированных в словаре В. И. Ааля поговорках «брянский волк» и «брянская коза» (Ааль, 2007: 131). Первая отсылает к древнейшему архетипу, играющему одну из ключевых ролей в формировании локальной мифологии (подробнее см.: Вороничева, 2016а). Вторая отражает полудеревенский уклад жизни города, а в составе пословицы «Он (она) - как брянская коза: все вверх глядит»интереснейшую доминанту его природного ландшафта - огромные овраги, в которые брянские мещанки водили коз на выгон (запутавшись на привязи, коза поднимала голову, высматривая свою хозяйку).

У истоков брянского текста короткие, но очень емкие высказывания о городе В. И. Немировича-Аанченко, В. В. Розанова и К. Г. Паустовского.

В. И. Немирович-Аанченко побывал в Брянске в 1882 г. проездом и увидел город из-за реки: «Когда мы вышли, перед нами раскинулась чудная картина. Ее красоте даже не могли повредить обнаженные сучья рощи и белые пятна снегу... Вдали... гористый берег Аесны с массой скученных над ним церквей, сверкающих под ярким блеском дня своими куполами, белыми стенами, колокольнями и крестами...» (Немирович-Аанченко, 1882: 336). Приведенное замечание можно считать первым словесным выражением достаточно четко сформированной сегодня тенденции понимать Брянск как 1) древнейший город православных святынь (подробнее см.: Вороничева, 2016с) и 2) топос с уникальным природным и культурным ландшафтом. Описание Немировича-Аанченко вполне соответствует снятому в 1852 г. арсенальским чертежником Гавриилом Васильевичем Хлудовым акварельному виду Брянска, на котором запечатлено обилие храмов. Изображены они на разных уровнях высоких холмов правого берега Аесны и составляют доминанту визуального облика старого города.

Результатом пятилетнего пребывания в Брянске (1882-1887) В. В. Розанова явилась небольшая по объему статья «Богоспасаемый городок» (Розанов, 2009). В ней завязаны узлы будущих магистральных тем брянского текста: православия (одно из первых впечатлений автора о Брянске - «церковь, белая, небольшая и красивая»); глубокой провинииальности и бедности ( Город был ужасающе беден и столь же ленив...»); древнейшей истории ( «город - старинный, один из древнейших в России»); железной дороги и брянского леса («Железная дорога все убила. Прежде был сплав леса по реке, и вот на сплаве построились богатые каменные дома в московском вкусе, где живут “сами”. Теперь сплава нет или ничтожен, да и лесов мало осталось, а если кому что купить, все покупают в Москве и везут по железной дороге»), административной, территориальной и содержательной неодноодности городского пространства («Были здесь и большие, даже огромные предприятия... но за чертою города и вне всякой с ним связи, кроме, так сказать, географического совпадения»); средоточия начиональной культуры (только «надышавшись такими маленькими провинциальными городами, как Брянск, можно судить о России»).

В «Аалеких годах» К. Г. Паустовского (Паустовский, 1995) Брянск 1909 г. внешне выглядит столь же гармонично и компактно, как и у Немировича-Аанченко: «Мы неслись среди блесткой снеговой пыли - сначала по дамбе, потом по Аесне. <...> Вда- 
ли на горах мерцал, как игрушка из фольги, старый город в мохнатых узорах из инея и сосулек» (там же: 161). С горой связаны воспоминания будущего писателя и о доме его дяди - Н. Г. Высочанского: «Сани остановились около деревянного дома на склоне горы»; «Иошади, перебирая ногами, спускались с крутой горы»; «За домом дяди Коли тянулся по крутому склону оврага старый яблоневый сад» (там же: $161,165,173)$.

Н. Г. Высочанский был военным инженером и с 20 августа 1900 г. служил на Брянском арсенале - старинном артиллерийском лафетном заводе (подробнее см.: Бобков, 2009), формировавшем отношение к Брянску как к городу с давними трудовыми традициями. Сфера деятельности, круг общения и образ жизни Высочанского повлияли на восприятие Брянска юным Паустовским, подолгу жившим у дяди: «Мне нравился арсенал, его низкие здания, построенные еще при Екатерине, дворы, заросшие муравой и заваленные чугунными отливками, сирень у стен мастерских, цилиндры старых паровых машин, блестевших маслянистой медью, запах спирта в лабораториях, бородатые кузнецы и литейщики и фонтан голубоватой артезианской воды, бившей из-под земли около стены арсенала» (там же: 174). Брянск для писателя связан еще и с летним театром в городском саду, на сцене которого выступал П. Н. Орленев. В «Аалеких годах» отмечается значимость этого события для городской интеллигенции: «Несколько дней в доме у дяди Коли говорили только об Орленеве» (там же: 167) и вместе с тем его неординарность и совершенная случайность для маленького уездного городка: «Театр был всегда заколочен» (там же: 168), «Козы срывали и сжевывали эти афиши. Изо рта у жующих коз торчали обрывки желтой бумаги с черными словами: “Гений... беспутство”. Только на немногих уцелевших афишах можно было прочесть, что Орленев выступит в Брянске в роли английского трагика Кина в пьесе “Кин, или Гений и беспутство” (там же: 168). Упоминания оврага и коз, отсылающие нас к поговорке брянская коза, еще раз акцентируют внимание на особом природном ландшафте города и его полудеревенском быте. Мысль о бедности, глубокой провинциальности и архитектурной безликости Брянска начала XX столетия подтверждают воспоминания о городе двоюродного брата Паустовского, Сергея Высочанского, переехавшего сюда с отцом из Киева в августе 1900 г.: «...маленький, деревянный, очень пыльный, плохо мощеный, без перспектив. Каменные здания - в основном казармы и Арсенал, несколько двухэтажных домов брянских миллионеров, купеческие лабазы - были лишены каких-либо достоинств» (Высочанский, 2000: 19).

В брянском тексте в дальнейшем будут концептуализированы намеченные В. В. Розановым и К. Г. Паустовским главные смыслопорождающие черты городской реальности. Глубоко оригинальное переосмысление многих из них находим в брянских рассказах $\Lambda$. И. Аобычина, творчество которого знаменует начало второго этапа развития брянского текста.

\section{ПОСАЕРЕВОАЮЦИОННЫЙ ПЕРИОА БРЯНСКОГО ТЕКСТА (1918 Г. - НАЧААО 1930-Х ГОАОВ)}

Брянский текст Аобычина - глубоко оригинальное, целостное по содержанию и структуре явление (подробнее см.: Вороничева, 2016b), отражающее основные реалии и тенденции развития социокультурного пространства Брянска 1920-1930-х годов и заключающее в себе мощный творческий заряд, который спустя почти столетие порождает новые смыслы. В этот относительно короткий исторический период глубоко провинциальный Брянск становится предметом напряженной рефлексии и глав- 
ным героем созданных здесь произведений талантливейшего писателя советской эпохи. Его рассказы являются структурообразующим элементом брянского текста, высшим его проявлением и утверждают само его право на существование.

Иегким штрихом обозначена Аобычиным тема содержательной неоднородности городского пространства. Так, в рассказах неоднократно подчеркивается полудеревенский быт горожан: «У ворот заблеяла коза» (Аобычин, 1999: 61); «Цвела картошка» (там же: 79); живущая в центре города Козлова «отправила Авдотью встречать корову и пошла на огород» (там же: 53). Однако в письмах встречаем замечание об индустриальном потенциале локуса: «...Брянск (губернский город)! Центр промышленности с 40 тысячами рабочих!» (там же: 263).

Если у Розанова река и железная дорога рассматриваются как конкурирующие способы организации жизни в Брянске, то у Аобычина, напротив, они выступают как философские и әстетические категории одного смыслового ряда и выражают идею духовной свободы и красоты наполненного движением пространства. Писателя интересует не их практическая значимость, а онтологическая сущность и вневременное значение как символов развития и обновления.

В «брянских» рассказах Аобычин, как и Розанов в «Богоспасаемом городке», акцентирует внимание на бедности и губительном однообразии провинщиальной действительности - «Часто пили друг у друга чай...» (там же: 54); «Отец, приподняв брови, думал над пасьянсом. Мать порола ватерпруф. Сорокина раскрыла книгу из библиотеки. Тикали часы. Били. Тикали. Собака за окном лаяла по-зимнему» (там же: 81). Подобным образом брянская реальность оценивается Аобычиным и в письмах: «Вы писали, что у нас всегда что-то случается, - а только и случается, что дождь то перестанет идти, то опять пойдет» (там же: 312). Мотив бедности усилен демонстрацией отрицательной динамики пространства, проявляющейся в движении от цивилизации к варварству: «Вот все развалится, - вздыхала Кукина, качая головой на покосившиеся и подпертые бревнами домики: - где тогда жить?» (там же: 58).

Аинамика культурного ландшафта этого периода выражена в смене смысловой доминанты - религиозной на атеистическую. Так, в рассказе «Отец» менее чем на полутора страницах автор дважды высвечивает характерную деталь - разбитые стекла церкви. Образ Брянска безбожного запечатлели и брянские СМИ: «Чего только стоят заголовки газеты “Брянский рабочий” того времени: “За ликующим перезвоном пасхальных колоколов скрывается хитрое лицо классового врага” (23 апреля 1929 г.); “Заглушим пасхальный звон” (4 мая 1929 г.); “Пусть песнь труда заглушит пасхальный перезвон колоколов" (5 мая 1929 г.) и "Пусть смолкнут колокола, пусть громче гудят станки!”; “Аолой колокольный звон” (7 января 1930 г.); “Выполняем волю рабочих. Брянск - город без колокольного звона” (8 января 1930 г.) и т. д. Председатель Союза воинствующих безбожников Емельян Ярославский назвал Брянск среди городовинициаторов движения по уничтожению колоколов в СССР» (Соловьев, Электронный ресурс). Красноречивым примером десакрализации пространства, отразившимся, в том числе, в рассказах Аобычина и советской периодике, является эволюция образа Новопокровского собора, утратившего свое культовое значение и переоборудованного под Народный клуб имени 25 октября (1925 г.) и антирелигиозный музей (1929 г.).

В апреле 1919 г. у стен собора захоронили первого председателя Брянского совета Игната Ивановича Фокина. Утверждение культа этого пламенного борца за свободу и лидера брянских коммунистов продолжилось публикацией подборок стихов в бежицких и брянских известиях (подробнее см.: Киселева, 2012) и присвоением его имени 
одной из центральных улиц, входившему в состав города поселку, а также Бежицкому машиностроительному институту. Идейный сдвиг демонстрирует и смена памятника известному меценату Павлу Могилевцеву памятником Е. К. Ворошилову. Принципиально иным смыслом наполняются элементы оппозиции старое - новое. В рамках социалистической идеологии под старым понимается не свобода личного пространства (как это было у Аобычина), а косность, отсталость, угнетение и неграмотность. Новое - это не отчужденные от человека формы общественной жизни в виде, например, демонстраций и лозунгового сознания, а борьба за справедливость и коммунистическое строительство.

Наиболее интересной чертой революционного периода брянского текста является его эклектичность, емко выраженная Аобычиным: «Сорок восемь советских служащих пели на клиросе» (Аобычин, 1999: 51). Она стала следствием кардинальной перестройки системы ключевых образов под влиянием руководящей и направляюшей. С одной стороны, лишались сакральных смыслов и смещались на периферию культурного пространства атрибуты христианства. С другой - брянский текст насыщался революционным содержанием, и как следствие, создавался новый язык для его выражения. Несмотря на шумную социалистическую пропаганду, сегодня в брянском тексте гораздо слышнее негромкая добычинская нота, совершенно не актуальная для его современников. Аозунговая журналистика и литература, рукоплескавшая революции и составлявшая примету времени, не прошла его проверку и не стала достоянием культуры. Аеидеологизированный добычинский текст литературы стал главным богатством брянского текста. Ирония судьбы выражается в том, что ни Розановым, ни Аобычиным Брянск не осознавался как комфортный для жизни и творчества топос; более того, они рвались из Брянска, ощущая нехватку воздуха и свободы. Однако именно здесь были созданы выдающиеся произведения, составляющие славу русской философии (Розанов, 1995) и русской литературы (большинство произведений А. И. Аобычина).

\section{СОВЕТСКИЙ ПЕРИОА БРЯНСКОГО ТЕКСТА}

(НАЧААО 1930-Х ГОАОВ - 1985 Г.)

Брянский текст советского периода создался «сверху»; характеризовался смысловой целостностью и принципиальной новизной, был оторван от традиций, заложенных Розановым, Паустовским, Аобычиным. В нем преимущественно разрабатывались темы революционного прошлого, Великой Отечественной войны, трудовой и литературной славы Брянска. Созданию его нового словаря способствует появление многочисленных «революционных» годонимов: Аенина, Ульянова, Ильича, Сталина, Калинина, Корхова, Кубяка, Менжинского, Азержинского, XXII съезда КПСС, 50-летия Октября и др.

В контексте прославления революционных идеалов акцент делается на образах Аенина и Фокина. По подсчетам Информационного агентства «Город-24», с советских времен в современном Брянске сохранилось двенадцать памятников Ильичу (По Аенинским местам, 2012: Электронный ресурс). Актуализация ленинской темы приходится на юбилейный 1970 г. Главными событиями становятся издание брошюры «В. И. Аенин и Брянщина» (Иенин и Брянщина, 1970) и открытие памятника Ильичу на центральной площади Брянска, в нескольких десятках метров от памятника Аенину, установленному в 1946 г. взамен разрушенному в войну памятника 1929 г. (их недолгое сосуществование отразилось в городском фольклоре). 
Статус гения места закрепился за пламенным брянским революционером Игнатом Ивановичем Фокиным, образ которого разрабатывался на разных уровнях бытования брянского текста. На уровне виртуального пространства он раскрывается, например, в художественной литературе: «Но в литейках, // Где сталь формовали опоки, // Где рабочим рукам // Поддавался металл, // Подрастал помаленьку // Игнатушка Фокин,// Тот, который // Товарищем Фокиным стал» (Мехедов, 2015: 117). В 1988 г. в московском издательстве «Политиздат» вышла повесть Ю. И. Когинова «Недаром вышел рано» о Фокине (Когинов, 1988). В реальном пространстве память о вожде брянского пролетариата увековечивается открытием мемориальной доски на доме, в котором он жил, и установлением памятника (Фокинский район).

Как показало время, тема революционной истории существовала только на уровне идеологии и не затронула уровень социальной психологии. Совершенно иначе сложилась ситуация с темой Великой Отечественной войны. Интерес к ней, конечно, стимулировался сверху, но и без того она глубоко волновала людей, сполна переживших трагедию 1941-1945 гг. Более того, брянский текст советского периода создавался людьми фронтового поколения и поколения детей войны. О масштабах интереса к этой теме свидетельствует проникновение ее даже в народное творчество, прежде всего в пословицы, песни и частушки. В них отразились две важнейшие брянские реалии - лес и река: "Брянский лес - всей страны зашитник»; "Брянские чашобь для фашистов страшнее гроба»; "Хотел фашист в Аесне напиться, да не по вкусу пришлась водица»; "Брянские леса и реки похоронили врагов навеки» (см.: Пословицы и поговорки Брянской области, 2008).

В первые послевоенные десятилетия были обустроены многочисленные места памяти, посвященные подвигу народа в Великой Отечественной войне, до сих пор определяющие специфику брянского текста и самобытность визуального облика Брянска, укрепляющие его статус города-воина (подробнее см.: Вороничева, 2015а). Всеобъемность темы проявляется в том, что на ее материале и применительно к ней раскрываются другие темы брянского текста. Примером может служить довольно распространенный мотив войны и мира. На контрасте «смерть, / что принял на войне»- «жизнь, / что мы ему вернули» строится описание Брянска в стихотворении «Покуда сердце будет биться» И. Швеца (Швец, 1977: 20). Готовность к ратному и трудовому подвигу часто репрезентируется как основная черта брянского характера: «Наш город - борец и трудяга, Солдат и герой-партизан» (Брянск поэтами воспетый, 1974: 8).

Тема трудовой славы брянцев приоритетно разрабатывалась в искусстве, публицистике, культурном ландшафте. То с добрым мастером, то с заводом сравнивает Брянск В. Козырев: «Он вел меня, / как добрый мастер, / в нелегкий мир своих забот. / Он пах листвой, / машинным маслом/ и сам похож был на завод» (Козырев, 2010: 113). Город предстает в виде старшего друга и наставника, мудрого ( «вспоминать напоминал») и терпеливого ( «объяснять не уставал»). Примечательно, что цветущая сирень и шумящая листва - столь же необходимый атрибут города, сколь и «ключ и молот / в петлицах синеньких его». Мысль об органичном сочетании естественно-природного и механико-технологических элементов в культурном ландшафте города проводит и И. Швец: «Удивительны улицы летом, корпуса заводские в садах» (Швец, 1977: 20). Реконструированный в художественной литературе ландшафт индустриального Брянска кардинально отличается от ландшафта, почти столетие назад воспроизведенного Немировичем-Аанченко: «...дымят трубы могучих заводов Брянска, напоминая о том, что теперешняя Брянская область - это край индустриальный» (Цапенко, 
1972: 7); «Над Аесною седые холмы крутолобы. / Где ни стань, где ни глянь - корпуса, / Пролетарской, рабочей, испытанной пробы - / Город пальцами труб приподнял небеса. / За Аесною поля по-российски пологи. / От цветов на лугах - небеса голубей» (Мехедов, 2015: 118).

С изменением форм жизни и исчезновением натурального хозяйства в брянском тексте акцентировалось внимание на промышленной составляющей культурного ландшафта, перестали встречаться детали полудеревенского быта, ушел образ брянской козы. Ао сих пор мы с гордостью вспоминаем о том, что Брянск был развитым промышленным центром России и за успехи в хозяйственном и культурном строительстве награжден орденами Октябрьской Революции и Трудового Красного Знамени. Этот факт неоднократно переосмыслен поэтически: «И чье же сердце не забьется гордо, / В чье сердце не вольется торжество, / Когда дучистый прикрепляют орден / На пролетарском знамени его» (Мехедов, 2015: 117); «Ты носишь достойно награды / На мощной рабочей груди» (Брянск поэтами воспетый, 1974: 8).

Образ социалистического Брянска наполнился принципиально новым содержанием. Это уже не тихий патриархальный городок с обилием святых мест и уникальным природным ландшафтом, а типичный советский промышленный центр, в котором полноценно отражены процессы революционного строительства и разработан идеологически выверенный стандартный набор тем и сюжетов. В брянском тексте был реконструирован образ светлого советского настоящего, увековечен подвиг брянцев в годы Великой Отечественной войны, а также обозначена тема литературной славы Брянщины и России. Брянск позиционировался как центр края, прежде всего связанного с именем Тютчева. В 1960 г. в городе появился единственный в России бюст А. К. Толстого, а семью годами позже присвоено имя писателя центральному парку, в котором все было необычно для социалистической действительности: от увековечивания памяти писателя-графа, представителя чистого искусства, до степени свободы директора, поэта и бывшего фронтовика В. А. Аинабургского, заставившего деревянного старика-сказочника по утрам «петь» «Интерначионал». Это явление стоит особняком в советском периоде художественной жизни города, официальный характер которой выражался в динамике ее протекания: периоды активности соответствовали знаменательным датам. Явления, не вписывающиеся в рамки советской идеологии, уничтожались. Так, в 1982 г. по решению Брянского горсовета народных депутатов был снесен весь комплекс усадебных построек Аобычиных, в том числе переживший оккупацию старинный купеческий дом (первое архивное упоминание о нем относится к 1897 г.). Между тем именно здесь провел последние годы своего пребывания в Брянске и принял решение об отъезде в Менинград $\Lambda$. И. Аобычин.

Вследствие идеологического давления в брянском тексте эпохи СССР были заложены основы современных глубочайших противоречий. Например, Петропавловской улице было присвоено имя главного атеиста и гонителя церкви, а появившуюся рядом площадь назвали именем Революции. Сегодня отреставрированы и восстановлены исконно находившиеся здесь храмы, построен величественный Кафедральный собор. Все они оказались на улице Һенина и площади Революции. Не менее абсурдным представляется решение Брянского горсовета, принятое в ноябре 2016 г., установить мемориальную доску Аобычину на бывшем ведомственном доме обкома партии. Приведенные примеры свидетельствуют не о готовности власти и общественности целенаправленно, системно и профессионально устранять смысловые диссонансы 
брянского текста, а скорее о бессистемном и неуправляемом точечном воздействии на культурный ландшафт.

\section{БРЯНСКИЙ ТЕКСТ КАК ЯВАЕНИЕ КУАЬТУРЫ}

Современный период развития брянского текста совпадает по времени с активизацией общего интереса к культуре локальных сообществ и поиском национальной и городской идентичности. Как и революционный, он соотносятся с переходным временем социально-экономической нестабильности, сопровождается сменой идеологий и, как следствие, способов формирования.

Его начало знаменуют мероприятия 1985 г., связанные с празднованием 1000-летия Брянска и стимулировавшие интерес к реалиям городской действительности. Среди наиболее заметных событий отметим открытие мемориального комплекса на Покровской горе - в историческом центре Брянска. В скульптурном ансамбле было закреплено разнообразие тем, сложившихся к этому времени в брянском тексте: $1000-$ летней истории города, его военной и литературной судьбы, революционного прошлого и трудовой славы. На самой высокой точке географического ландшафта - более чем 40-метровом «мысу, образованном правым берегом реки Аесны, оврагом Верхний Судок и первым северным ответвлением этого оврага» (Гурьянов, 1995: 53), была установлена скульптурная композиция, состоящая из сидящего на коне древнего воина в боевом снаряжении, со щитом и пикой и Бояна с гуслями. Воина на коне в народе и официальных источниках (прежде всего СМИ) очень быстро нарекли именем брянского гения места Пересвета, что вряд ли соответствует логике истории: Пересвет, скорее, мог быть в монашеской рясе, а не в кольчуге. Но в нашем случае соотнесение поэта и воина, воплощенных в камне, с персонажами местной истории подтверждает мысль о значимости достижений брянцев в военной и литературной деятельности. Пересвет и Боян - ключевые образы брянского текста (по одной из гипотез, корни Бояна на Брянской земле). Как выразители культурных приоритетов региона, они организационно оформляют и задают основные направления его духовной деятельности. Эти гении места выступают в качестве «фактора формирования образа, некоей духовной проекции места, его одухотворения» (Иевинтов: Электронный ресурс).

Сегодня продолжается формирование индивидуального облика Брянска как наследника славы Бояна. «Одарил тебя песней Боян», - писал, обращаясь к Брянску, Валентин Аинабургский (Аинабургский, 2001: 119). Статус гениеb места закрепляется за Тютчевым, Толстым, отчасти за П. $\Lambda$. Проскуриным и $\Lambda$. И. Аобычиным (подробнее см.: Вороничева, 2015b: 128-134). В брянском тексте литературы воссоздается целостная картина «жизни той, что бушевала здесь» (Тютчев, 1978: 278) - на территории нынешнего Брянска.

В словесности, в городской мифологии, краеведении и публицистике утверждается образ Брянска как мужественного воина, стоящего на рубеже русской земли и готового к ратному и трудовому подвигу во имя ее защиты. Актуализируется значение Брянска как форпоста Московской Руси, с начала XVI в. занимавшего «очень важное место в оборонительной системе Русского государства» (Крашенинников, 2008: 9). Благодаря историческим аналогиям и сближениям новое звучание обрела тема Великой Отечественной войны. В силу своей искусственности и слабой укорененности в общественном сознании из брянского текста исчезла тема славного революционного прошлого. Ушла в историю тема трудового подвига брянцев в период советских пятилеток, однако мотив рабочей гордости продолжает звучать и раскрывается преиму- 
щественно на историко-культурном материале. Слышней стал мотив ландшафтной самобытности Брянска, во многом определившей стиль жизни и менталитет горожан, четко обозначились образы православия, железной дороги, брянского волка.

\section{ЗАКАЮЧЕНИЕ}

Как видим, несмотря на глубокие истоки, брянский текст начал формироваться относительно недавно, с конца XIX столетия. Его вершинная точка совпадает с творчеством Аобычина, после которого на семь десятилетий теряется интерес к самобытности локуса. Меняются способы формирования брянского текста, используемого как средство идеологического воздействия. Рубежным можно признать 1985 г., а его ценнейшее приобретение - Покровскую гору - отдельной семиотической системой, полноценно реализующей главную идею брянского текста - «седой старины», определившей предназначение, облик и судьбу Брянска. Эта идея определяет ракурс раскрытия всех тем, мотивов и образов, в том числе темы трагедии и подвига брянцев в Великой Отечественной войне, осмысливаемой в широком контексте ратной славы города и наиболее полно и последовательно раскрываемой в брянском тексте. Его смысловой константой, в которой, несмотря на все идеологические наслоения, всегда сохранялась суть древнего города, является астионим Брянск.

\section{СПИСОК АИТЕРАТУРЫ}

Абашев, В. В. (2000) Пермь как текст. Пермь в русской культуре и литературе XX века. Пермь : ИзА-во Пермского университета. 404 с.

Анциферов, Н. П. (1990) Ауша Петербурга. А. : Аира. 249 с.

Бобков, В. А. (2009) Жизнь и деятельность Н. Г. Высочанского на брянской земле // Вестник Брянского государственного университета. № 2. С. 6-12.

Брянск поэтами воспетый (1974) / сост. В. А. Аинабургский. Брянск : Брянское городское отделение общества любителей книги. 25 с.

Вороничева, О.В.(2015а) Великая Отечественная война как главная тема брянского текста // Вестник Челябинской государственной академии культуры и искусств. № 4 (44). С. 159-165.

Вороничева, О. В. (2015b) «Гений места» как смыслообразующий элемент локального теста (на примере Брянска) // Проблемы и тенденции развития социокультурного пространства России: история и современность: материалы международной научно-практической конференции (Брянск, 24-25 апреля 2015 г.). Брянск : БГИТА. С. 128-134.

Вороничева, О. В. (2016а) Архетип волка в брянском тексте // Современный город: власть, управление, экономика: Всероссийская научно-практическая конференция (Пермь, 27-28 апреля 2016 г.). Вып. VI. Пермь : Пермский национальный исследовательский политехнический университет. 326 с. С. 251-259.

Вороничева, О. В. (2016b) Брянский текст $\Lambda$. Аобычина // Культурное наследие России. № 2 (13). C. 84-89.

Вороничева, О. В. (2016с) Специфика осмысления православных святынь в брянском тексте// Человек и культура. №5. С. 75-82.

Высочанский, С. Г. (2000) Наша семья. Ее прошлое // Мир Паустовского. № 15-16. С. 14-22.

Гаврилина, $\Lambda$. М. (2011) Калининградский текст в семиотическом пространстве культуры // Вестник Балтийского федерального университета им. И. Канта. Серия: Гуманитарные и общественные науки. №6. С. 75-83.

Голубев, Н. А. (2014) Формирование локального текста: ивановский опыт : дис. ... канд. филол. наук. Иваново. 241 с.

Гурьянов, В. Н. (1995) Новые данные о древнерусском Брянске // Из истории Брянского края: материалы юбилейной историко-краеведческой конференции, посвященной 50-летию об- 
разования Брянской области и 50-летию Победы в Великой Отечественной войне $(23$ марта 1995) / Брянск. обл. краевед. общ-во, Брянск. гос. пед. ун-т им. И. Г. Петровского. Брянск : БГПИ. 231 с. С. 52-56.

Ааль, В. И. (2007) Толковый словарь живого великорусского языка : в 4 т. М. : Русский языкМедиа. Т. 2.779 с.

Аинабургский, В. А. (2001) Аунарий. Брянск : ИзА-во Брянской торгово-промышленной палаты. 139 с.

Аобычин, А. И. (1999) Полное собрание сочинений и писем. СПб. : Звезда. 544 с.

Киселева, Е. В. (2012) Пролетарские поэты Орловской губернии: коллективный портрет проводников образов власти // Брянский край в XX в.: общество, политика, экономика : сб. статей и материалов научно-практической историко-краеведческой конференции / ред. кол.: М. В. Брянцев, А. М. Аубровский, Е. В. Киселева. Брянск : Аадомир. 188 с. С. 104-119.

Когинов, Ю. И. (1988) Недаром вышел рано : повесть об И. Фокине. М. : Политиздат. 331 с.

Козырев, В. С. (2010) Точка дальнего огня // Аитературный Брянск. № 1 (8). С. 113-117.

Крашенинников, В. В. (2008) Очерки по истории Брянской земли : сб. науч. ст. Брянск : БОНУБ. 156 с.

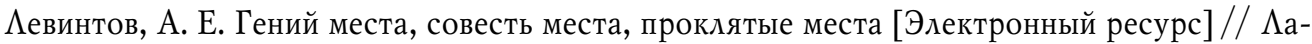
биринт: журнал социально-гуманитарных исследований. URL: http://journal-labirint.com/?p= 2721 (дата обращения: 16.03.2015).

Иенин и Брянщина (1970) : сб. документов и материалов / под ред. И. И. Фишмана. Тула : Приокское книжное издательство. 207 с.

Цотман, Ю. М. (1993) Город и время // Петербургские чтения по теории, истории и философии культуры / отв. ред. А. Морева. Вып. 1. СПб. : ФКИЦ «ЭЙАОС». 319 с. С. 84-92.

Аюсый, А. П. (2012) Текстуальная революция или семиотическая мутация? Об одном культурологическом путешествии в петербургской маршрутке, концептуализированном пробкой на улице Пестеля [Электронный ресурс] // Культурологический журнал. №2 (8). URL: http:// cr-journal.ru/rus/journals/123.html\&j_id=10 (дата обращения: 08.04.2017).

Аюсый, А. П. (2015) Крымский текст и семантические войны [Электронный ресурс]// Русская идея: сайт политической консервативной мысли. 27 июля. URL: http:// politconservatism.ru/ experiences/krymskiy-tekst-i-semanticheskie-voyny/ (дата обращения: 23.08.2015).

Мехедов, А. Г. (2015) Вечный огонь // Аитературный Брянск. № 1 (9). С. 116-119.

Немирович-Аанченко, В. И. (1882) Америка в России // Русская мысль. № 1. С. 318-355.

Паустовский, К. Г. (1995) Аалекие годы // Паустовский, К. Г. Избранные произведения : в 3 т. М. : Русская книга. Т. 1.720 с. С. $25-279$.

По Иенинским местам (2012) [Электронный ресурс] // ГородБРЯНСК.Ru. 24 июня. URL: http://gorod-24.livejournal.com/13464522.html (дата обращения: 06.12.2016).

Пословицы и поговорки Брянской области (2008)/ В. А. Глебов. Брянск : БГУ. 325 с.

Розанов, В. В. (2009) Богоспасаемый городок // Розанов, В. В. Собрание сочинений. Т. 7. Юдаизм. Статьи и очерки 1898-1901 гг. М. : Республика ; СПб. : Росток. 845 с. С. 645-649.

Розанов, В. В. (1995) Сочинения: О понимании. Опыт исследования природы, границ и внутреннего строения науки как цельного знания. М. : Танаис. 808 с.

Соловьев, Ю. П. Обезглавленные храмы [Электронный ресурс] // sites.google.com. URL: https://sites.google.com/site/urijsoloveev/obezglavlennye-hramy (дата обращения: 28.03.2016).

Топоров, В. Н. (1995) Петербург и «Петербургский текст русской литературы»// Топоров, В. Н. Миф. Ритуал. Символ. Образ. Исследования в области мифопоэтического: Избранное. М. : Издательская группа «Прогресс»; Культура. 624 с. С. 259-367.

Тютчев, Ф. И. (1978) Стихотворения и письма/ вступ. статья, сост. и примеч. Е. Н. Мебедева. М. : Современник. 415 с.

Цапенко, М. П. (1972) Земля Брянская. М. : Искусство. 135 с.

Швец, И. А. (1977) Стихи и поэмы. Тула: Приокское книжное издательство. 236 с. 


\section{BRYANSK TEXT: WAYS AND MEANS OF ITS FORMATION \\ O. V. VORONICHEVA \\ BRYANSK STATE TECHNOLOGICAL UNIVERSITY OF ENGINEERING}

The paper is written within the framework of the semiotic approach to the study of a town, which is regarded as a text, i. e. in the unity of the elements that constitute its semantic field and perform a sign function. The subject of the analysis is the process and result of space symbolisation, taking place in a particular Central Russian town dating back over 1000 years.

The author identifies and describes four main periods of the Bryansk text development: 1) preparatory period (the early 1880s-1917); 2) post-revolutionary period (1918 - the early 1930); 3) Soviet period (the early 1930s-1985); 4) modern period (since 1985). All these different, sometimes mutually exclusive according to the dominant idea and content, levels are built into a single unit due to the system of sustainable images, whose ratio and place in the cultural space of Bryansk varied greatly depending on the ideological component of the epoch. The ways of the Bryansk text formation exert a decisive influence on the content and intensity of its development. A much greater ideological and thematic diversity is shown by the revolutionary and modern periods, correlated with the change of ideology, but not the Soviet period, which is characterised by total control of authorities over all processes in the cultural sphere.

The research revealed the origins of the ideological and thematic diversity, internal logic, and contradictions of the Bryansk text, the etymology of its semantic constants. Its highest point has been defined, and it coincides with the oeuvre of L. I. Dobychin, after whom the interest to the unique identity of locus was lost for seven decades, and the ways of the Bryansk text formation were changed. Pokrovskaya Gora is described as a separate semiotic system, which fully implements the main idea of the Bryansk text and plays a special role in revealing the image of Bryansk as a warrior town, originally standing on the defence line of the Russian land. The paper highlights the significance of the astyonym Bryansk in providing a semantic unity of the Bryansk text and maintaining the essence of an ancient town with a special historical destiny and landscape.

Keywords: semiotic system; Bryansk; Bryansk text; cultural landscape; semantic constants

\section{REFERENCES}

Abashev, V. V. (2000) Perm' kak tekst. Perm'v russkoi kul'ture i literature XX veka. Perm', Izd-vo Permskogo universiteta. 404 p. (In Russ.).

Antsiferov, N. P. (1990) Dusha Peterburga. Leningrad, Lira. 249 p. (In Russ.).

Bobkov, V. A. (2009) Zhizn' i deiatel'nost' N. G. Vysochanskogo na brianskoi zemle. Vestnik Brianskogo gosudarstvennogo universiteta, no. 2, pp. 6-12. (In Russ.).

Briansk poetami vospetyi (1974) / comp. by V. D. Dinaburgskii. Briansk, Brianskoe gorodskoe otdelenie obshchestva liubitelei knigi. 25 p. (In Russ.).

Voronicheva, O. V. (2015a) Velikaia Otechestvennaia voina kak glavnaia tema brianskogo teksta. Vestnik Cheliabinskoi gosudarstvennoi akademii kul'tury $i$ iskusstv, no. 4 (44), pp. 159-165. (In Russ.).

Voronicheva, O. V. (2015b) «Genii mesta» kak smysloobrazuiushchii element lokal'nogo testa (na primere Brianska). In: Problemy $i$ tendentsii razvitiia sotsiokul'turnogo prostranstva Rossii: istoriia $i$ sovremennost': materialy mezhdunarodnoi nauchno-prakticheskoi konferentsii (Briansk, 24-25 aprelia 2015 g.). Briansk, BGITA. Pp. 128-134. (In Russ.).

Voronicheva, O. V. (2016a) Arkhetip volka v brianskom tekste. In: Sovremennyi gorod: vlast', upravlenie, ekonomika: Vserossiiskaia nauchno-prakticheskaia konferentsiia (Perm', 27-28 aprelia 2016 g.). Vol. VI. Perm', Permskii natsional'nyi issledovatel'skii politekhnicheskii universitet. 326 p. Pp. 251-259. (In Russ.).

Voronicheva, O. V. (2016b) Brianskii tekst L. Dobychina. Kul'turnoe nasledie Rossii, no. 2 (13), pp. 84-89. (In Russ.).

Voronicheva, O. V. (2016c) Spetsifika osmysleniia pravoslavnykh sviatyn' v brianskom tekste. Cbelovek i kul'tura, no. 5, pp. 75-82. (In Russ.). 
Vysochanskii, S. G. (2000) Nasha sem’ia. Ee proshloe. Mir Paustovskogo, no. 15-16, pp.14-22. (In Russ.).

Gavrilina, L. M. (2011) Kaliningradskii tekst v semioticheskom prostranstve kul'tury. Vestnik Baltiiskogo federal' nogo universiteta im. I. Kanta. Seriia: Gumanitarnye i obshchestvennye nauki, no. 6, pp. 75-83. (In Russ.).

Golubev, N. A. (2014) Formirovanie lokal'nogo teksta: ivanovskii opyt : Dis. ... Candidate of Philology. Ivanovo. 241 p. (In Russ.).

Gur'ianov, V. N. (1995) Novye dannye o drevnerusskom Brianske. In: Iz istorii Brianskogo kraia: materialy iubileinoi istoriko-kraevedcheskoi konferentsii, posviashchennoi 50-letiiu obrazovaniia Brianskoi oblasti i 50-letiiu Pobedy v Velikoi Otechestvennoi voine (23 marta 1995) / Briansk. obl. kraeved. obshch-vo, Briansk. gos. ped. un-t im. I. G. Petrovskogo. Briansk, BGPI. 231 p. Pp. 52-56. (In Russ.).

Dal', V. I. (2007) Tolkovyi slovar' zhivogo velikorusskogo iazyka : in 4 vol. Moscow, Russkii iazyk - Media. Vol. 2. 779 p. (In Russ.).

Dinaburgskii, V. D. (2001) Lunarii. Briansk, Izd-vo Brianskoi torgovo-promyshlennoi palaty. 139 p. (In Russ.). Russ.).

Dobychin, L. I. (1999) Polnoe sobranie socbinenii i pisem. St. Petersburg, Zvezda. 544 p. (In

Kiseleva, E. V. (2012) Proletarskie poety Orlovskoi gubernii: kollektivnyi portret provodnikov obrazov vlasti. In: Brianskii krai $v X X$ v.: obshchestvo, politika, ekonomika : sb. statei $i$ materialov nauchno-prakticheskoi istoriko-kraevedcheskoi konferentsii / ed.-in-board: M. V. Briantsev, A. M. Dubrovskii and E. V. Kiseleva. Briansk, Ladomir. 188 p. Pp. 104-119. (In Russ.).

Koginov, Iu. I. (1988) Nedarom vyshel rano : povest' ob I. Fokine. Moscow, Politizdat. 331 p. (In Russ.).

Kozyrev, V. S. (2010) Tochka dal'nego ognia. Literaturnyi Briansk, no. 1 (8), pp. 113-117. (In Russ.).

Krasheninnikov, V. V. (2008) Ocherki po istorii Brianskoi zemli : sb. nauch. st. Briansk : BONUB. 156 p. (In Russ.).

Levintov, A. E. Genii mesta, sovest' mesta, prokliatye mesta. Labirint: zhurnal sotsial'no-gumanitarnykh issledovanii [online] Available at: http://journal-labirint.com/?p=2721 (accessed: 16.03.2015). (In Russ.).

Lenin i Brianshchina (1970) : sb. dokumentov i materialov / ed. by I. I. Fishman. Tula, Priokskoe knizhnoe izdatel'stvo. 207 p. (In Russ.).

Lotman, Iu. M. (1993) Gorod i vremia. In: Peterburgskie chteniia po teorii, istorii i filosofii kul' tury / ed. by L. Morev. Vol. 1. St. Petersburg, FKITs «EIDOS». 319 p. Pp. 84-92. (In Russ.).

Liusyi, A. P. (2012) Tekstual'naia revoliutsiia ili semioticheskaia mutatsiia? Ob odnom kul'turologicheskom puteshestvii $\mathrm{v}$ peterburgskoi marshrutke, kontseptualizirovannom probkoi na ulitse Pestelia. Kul'turologicheskii zhurnal, no. 2 (8) [online] Available at: http://cr-journal.ru/rus/journals/123.html\&j_id=10 (accessed: 08.04.2017). (In Russ.).

Liusyi, A. P. (2015) Krymskii tekst i semanticheskie voiny. Russkaia ideia: sait politicheskoi konservativnoi mysli, Jul 7 [online] Available at: http://politconservatism.ru/experiences/krymskiytekst-i-semanticheskie-voyny/ (accessed: 23.08.2015). (In Russ.).

Mekhedov, A. G. (2015) Vechnyi ogon'. Literaturnyi Briansk, no. 1 (9), pp. 116-119. (In Russ.).

Nemirovich-Danchenko, V. I. (1882) Amerika v Rossii. Russkaia mysl', no. 1, pp. 318-355. (In Russ.).

Paustovskii, K. G. (1995) Dalekie gody. In: Paustovskii, K. G. Izbrannye proizvedeniia : in 3 vol. Moscow, Russkaia kniga. Vol. 1. 720 p. Pp. 25-279. (In Russ.).

Po Leninskim mestam (2012). GorodBRIaNSK.Ru, June 24 [online] Available at: http://gorod24.livejournal.com/13464522.html (accessed: 6.12.2016). (In Russ.).

Poslovitsy i pogovorki Brianskoi oblasti (2008)/ V. D. Glebov. Briansk, BGU. 325 p. (In Russ.).

Rozanov, V. V. (2009) Bogospasaemyi gorodok. In: Rozanov, V. V. Sobranie sochinenii. Moscow, Respublika ; St. Petersburg, Rostok. Vol. 7. Iudaizm. Stat'i i ocherki 1898-1901 gg. 845 p. Pp. 645-649. (In Russ.). 
Rozanov, V. V. (1995) Socbineniia: O ponimanii. Opyt issledovaniia prirody, granits i vnutrennego stroeniia nauki kak tsel' nogo znaniia. Moscow, Tanais. 808 p. (In Russ.).

Solov'ev, Iu. P. Obezglavlennye khramy. sites.google.com [online] Available at: https://sites. google.com/site/urijsoloveev/obezglavlennye-hramy (accessed: 28.03.2016). (In Russ.).

Toporov, V. N. (1995) Peterburg i «Peterburgskii tekst russkoi literatury». In: Toporov, V. N. Mif. Ritual. Simvol. Obraz. Issledovaniia v oblasti mifopoeticheskogo: Izbrannoe. Moscow, Izdatel'skaia gruppa «Progress»; Kul'tura. 624 p. Pp. 259-367. (In Russ.).

Tiutchev F. I. (1978) Stikbotvoreniia i pis'ma / vstup. stat'ia, sost. i primech. E. N. Lebedeva. Moscow, Sovremennik. 415 p. (In Russ.).

Tsapenko, M. P. (1972) Zemlia Brianskaia. Moscow, Iskusstvo. 135 p. (In Russ.).

Shvets, I. A. (1977) Stikbi i poemy. Tula, Priokskoe knizhnoe izdatel'stvo. 236 p. (In Russ.).

Submission date: 15.04.2017.

Вороничева Ольга Викторовна - кандидат филологических наук, доцент кафедры философии, истории и социологии Брянского государственного инженерно-технологического университета. Адрес: 241037, г. Брянск, пр-т Станке Аимитрова, д. 3. Тел.: +7 (919) 197-77-29. Эл. aspec: voronicheva.olga@yandex.ru

Voronicheva Olga Viktorovna, Candidate of Philology, Associate Professor, Department of Philosophy, History and Sociology, Bryansk State Technological University of Engineering. Postal address: 3, Stanke Dimitrova Ave., Bryansk, Russian Federation, 241037. Tel.: +7 (919) 197-77-29. E-mail: voronicheva.olga@yandex.ru 